\title{
A Rare Case: Malignant Granular Cell Tumor in Axillary Region
}

\author{
Nadir Bir Olgu: Aksiller Bölgede Malign Granüler Hücreli Tümör
}

\section{(D) Burak Ergün Tatar, (D) Caner Gelbal, (D Melihcan Sezgiç, (D) Perçin Karakol, (D Can Uslu, (D Selva Kabul}

University of Health Sciences, İstanbul Bağcllar Training and Research Hospital, Clinic of Plastic Surgery, İstanbul, Turkey

\section{Abstract}

Granular cell tumors (GCT) are rare soft tissue tumors. Although it is frequently seen in the upper extremity, it can be seen anywhere in the human body. The majority of tumor cases are benign and approximately $2 \%$ are malignant. It is seen in the breast at a rate of $5-8 \%$. They present with a slow growing, painless, mobile mass. The definitive diagnosis is made histopathologically and the treatment is wide excision. A 75-yearold woman presented with an ulcerated exudative mass in the right axilla. Mastectomy and axillary dissection were performed by general surgery 8 months ago for BIRADS 3 mass that was determined on mammography in the right breast. Breast specimen was identified as a phyllodes tumor. GCT was detected in five of thirty Imph nodes in the axilla. Incisional biopsy was performed on the axillary mass. Histopathological measurements showed S-100 and CD68 positivity, eosinophilic staining in tumor cells and pleomorphic nuclei with marked nucleolus. The tumor was removed with wide excision and the defect area was closed with a splint thickness skin graft. The pathological measurements revealed that the GCT in the axilla was not a breast metastasis, it was actually malignant GCT which was originated from skin. Ki-67 proliferation index was found as $10 \%$. Surgical margins were seen as tumor free. There were no complications in the postoperative follow-up. GCTs in the axilla are generally seen as a result of breast metastasis and the vast majority are benign. Malignant skin-derived GCT is a rare case.

Keywords: Granular cell tumor, axillary, rare tumors

\section{Öz}

Granüler hücreli tümör (GHT) nadir görülen yumuşak doku tümörüdür. Sıklıkla üst ekstremitede görülse de vücudun herhangi bir yerinde görülebilir. Tümör olgularının büyük çoğunluğu benigndir yaklaşık \%2'lik kısmı maligndir. Tümör \%5-8 oranında memede görülmektedir. Yavaş büyüyen, ağrısız, mobil kitle ile ortaya çıkar. Kesin tanı histopatolojik olarak konulmaktadır. Tedavisi geniş eksizyondur. Yetmiş beş yaşında kadın hasta sağ aksillada ülsere eksüdalı kitle ile başvurdu. Sekiz ay önce sağ memedeki mamografi sonucu BIRADS 3 olan kitle için genel cerrahi tarafından mastektomi ve aksiller diseksiyon yapıldı. Meme patolojisi filloides tümör olarak belirlendi. Aksilladaki otuz lenf nodundan beş tanesinde GHT'ye rastlandı. Aksilladaki kitleye insizyonel biyopsi yapıldı. Histopatolojik ölçümlerde S-100 ve CD-68 pozitifliği, tümör hücrelerinde eozinofilik boyanma ile belirgin nükleolusua sahip pleomorfik nükleuslar görülmüştür. Tümör geniş eksizyonla çıkartıldı defekt alanı kısmi kalınlıkta deri greft ile kapatıldı. Patolojik ölçümlerde aksilladaki GHT'nin meme metastazı olarak değil, deri kaynaklı malign GHT'si olduğu belirlendi. Ki67 proliferasyon indeksi \%10 olarak saptandı. Cerrahi sınırlar salim olarak görüldü. Hastanın postoperatif takiplerinde herhangi bir komplikasyona rastlanmadı. Aksilladaki GHT'ler genel olarak meme metastazı sonucu görülmektedir ve büyük çoğunluğu benigndir. Malign deri kaynakı GHT nadir görülen bir olgudur.

Anahtar kelimeler: Granüler hücreli tümör, aksilla, nadir tümörler

\section{Introduction}

Granular cell tumor (GCT) is a rare soft tissue tumor that is usually seen in the head, neck, skin, abdomen, upper extremity, breast and female genital organs (1). It was first described in 1854 by Weber and Virchow (2) in a patient's tongue. Also it was defined by Abrikossoff (3) in 1926 in the breast and named as granular cell myoblastoma. It is generally seen in African-American women in the perimenopausal period (4). Although estrogen and progesterone may be thought to play role for pathogenesis, most cases are hormone receptor negative.

Address for Correspondence: Burak Ergün Tatar, University of Health Sciences, İstanbul Bağcılar Training and Research Hospital, Clinic of Plastic Surgery, İstanbul, Turkey

E-mail: burakerguntatar@gmail.com ORCID ID: orcid.org/0000-0002-5446-1940 Received: 10.09.2019 Accepted: 11.11.2019

Cite this article as: Tatar BE, Gelbal C, Sezgiç M, Karakol P, Uslu C, Kabul S. A Rare Case: Malignant Granular Cell Tumor in Axillary Region. Bagcilar Med Bull 2019;4(4):106-109

๑Copyright 2019 by the Health Sciences University, Bagcilar Training and Research Hospital Bagcilar Medical Bulletin published by Galenos Publishing House. 
Initially it was thought that GCT was derived from skeletal muscle cells. Because of the S-100 protein positivity of tumor cells, it was found that it originated from neurogenic mesenchymal cells, especially Schwann cells $(5,6,7,8,9)$. The definitive diagnosis is made by histopathological confirmation. The most effective treatment is wide excision.

$5-8 \%$ of GCTs are seen in the breast $(1,6)$. It is very important to distinguish the tumor from breast cancer because the similarity between the two entities is remarkable, especially at the diagnostic stage. In this case, we present a patient who underwent mastectomy and axillary lymph node dissection due to breast cancer and a biopsy of the mass in the axillary region of the same side revealed a malign GCT derived from skin not breast.

\section{Case Report}

Seventy-five years old female presented to our clinic with complain of mass in her axillar region (Figure 1). Physical examination revealed that there was a mastectomy scar with her right side and approximately $7 \times 8 \mathrm{~cm}$ mass which is painless, exudative and ulcerated. Before eight month ago patient refered to general surgery department for painless mass in her right breast and right axillar region. Mammography revealed that there was lesion which was a stage of BIRADS 3 (Breast Imaging Reporting and Data System), which shows generally benign lesion. Mastectomy and axillary dissection were performed and for breast specimen benign phyllodes tumor was diagnosed by postoperative histopathologic examination. Five of thirty lymph nodes from which removed axilla were diagnosed as GCT. Incisional biopsy was performed lesion and pathology reports confirmed GCT. After written informed consent

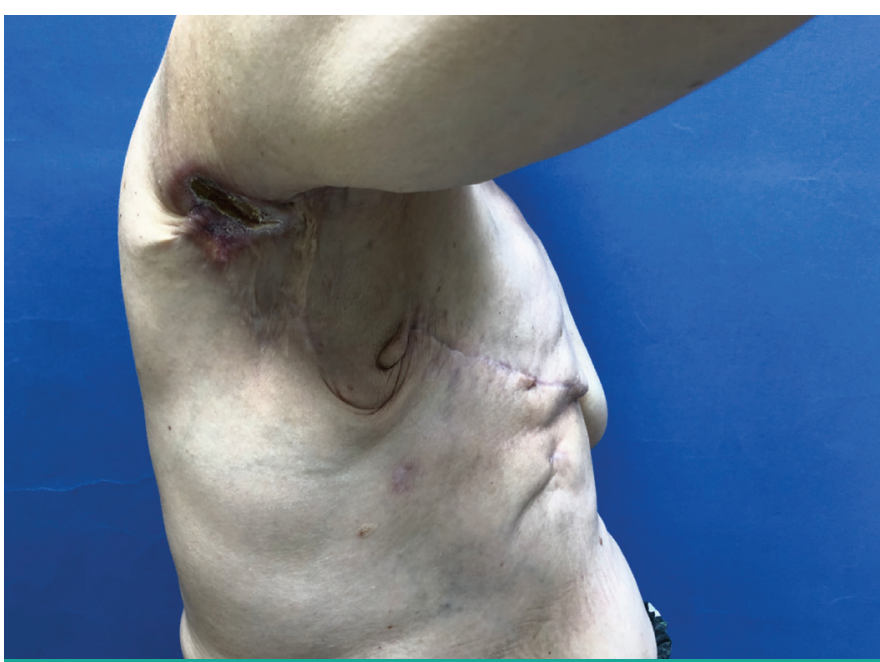

Figure 1. Preoperative view that is appropriate to Declaration of Helsinki was obtained from the patient. Under general anesthesia the patient was underwent excisional biopsy with $1 \mathrm{~cm}$ surgical margin and area where tumor was removed was covered with splint thickness skin graft (Figure 2). Histological evalutaion of surgical specimens revealed macroscopically grayish yellowish colored solid lesion that setteled under skin and caused ulcer. Also with Hematoxylin and Eosin stain on magnification $\mathrm{x} 100$ and $\mathrm{x} 200$ the fact that tumor cells had pleomorphic nuclei with prominent nucleolus and solid pattern infiltration of tumor cells with eosinophilic granules cytoplasm were seen. Showing diffuse strong immunostaining with S-100 protein was observed

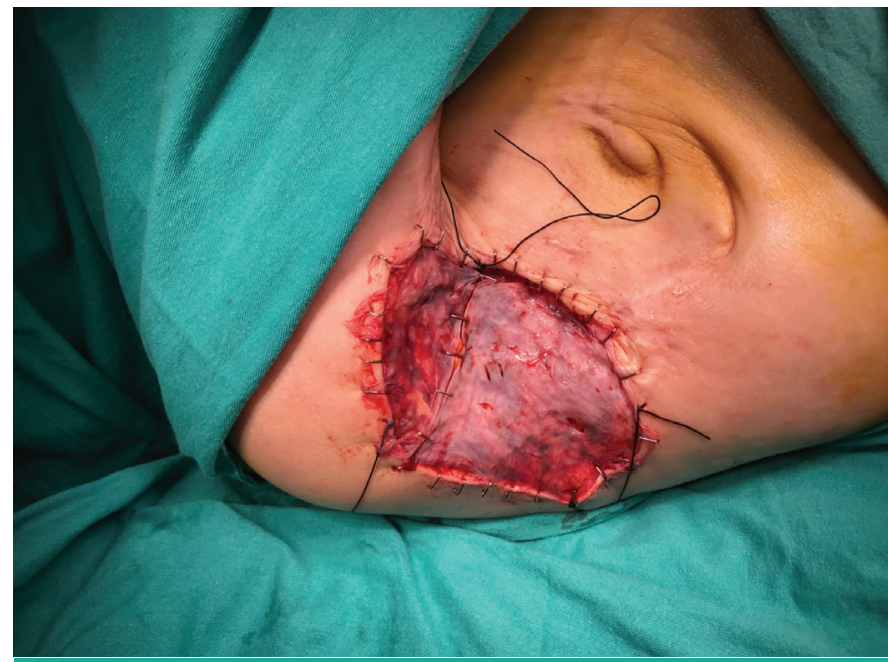

Figure 2. After tumor resection covered with splint thickness skin graft
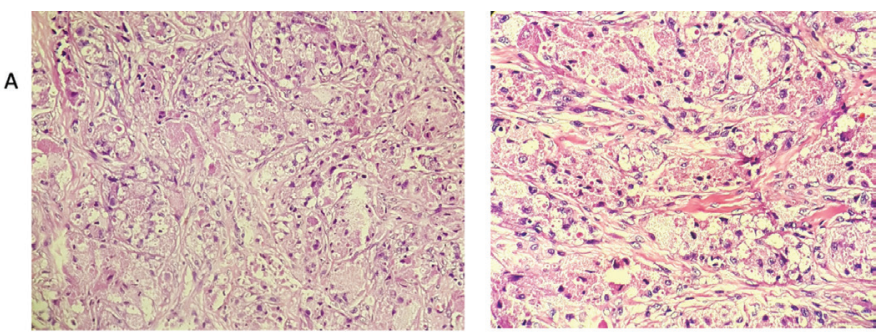

B
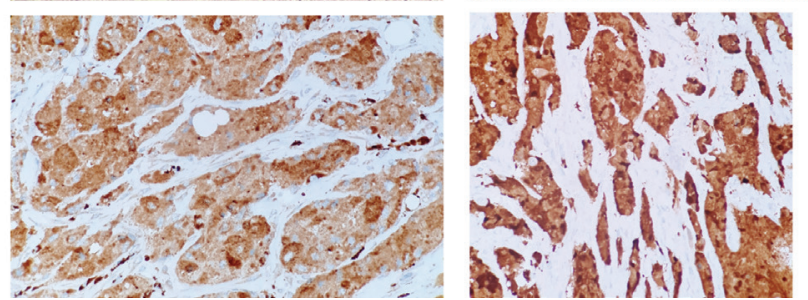

Figure 3. Tumor cells have plemorphic nuclei with prominent nucleous and solid patern infiltration of tumor cells with eosinophilic granules cytoplasm with Hemotoxylin and Eosin stain on magnification x100 and x200, respectively (A). Diffuse strong immunostaining with S-100P protein and CD-68, respectively (B) 
and tumor cells showed $10 \% \mathrm{Ki}-67$ proliferation index (Figure 3). Tumor was diagnosed as malign GCT derived from skin by patology department because of mentioned above and they reported all surgical margins were safe and tumor-free. After follow up period no complications were seen at the wound site and the graft was intact (Figure 4).

\section{Discussion}

Cases of GCTs, first described in 1854, have increased over the years. It composes $0.5 \%$ of all soft tissue tumors (10). Although it is generally seen in adult women, it has been reported in children. The majority of tumor cases are benign, but about $2 \%$ are malignant and also $5-10 \%$ are multiples (1). Although the most common site is the head and neck region also skin, heart, lung, abdominal wall, pelvis, bladder, vulva and esophagus are parts of the body where the tumor is seen. $(11,12,13,14,15,16,17,18)$ Clinical presentation varies depending on localization, but generally presents with slow-growing painless mobile masses.

The origin of GCTs were thought to be myocytes, histiocytes, fibroblasts in the first years, but histochemical tests showed that the tumor originated from neural cells especially Schwann cells (1). Alpha tubulin, cytokeratin, inhibin and calterin negativity proves that the tumor is not orginated from epithelial cells. Tumor cells shows S-100 the protein positivity which is secreted from neural cells and melanocytes. Tumor is stained with CD68 and Neuron Specific enolase. CD68 is a marker of lysosomal activity in Schwann cells. Enolase is also secreted from neural cells (Carcinoembryonicantigen) and vimentin positivity have been reported in some cases.

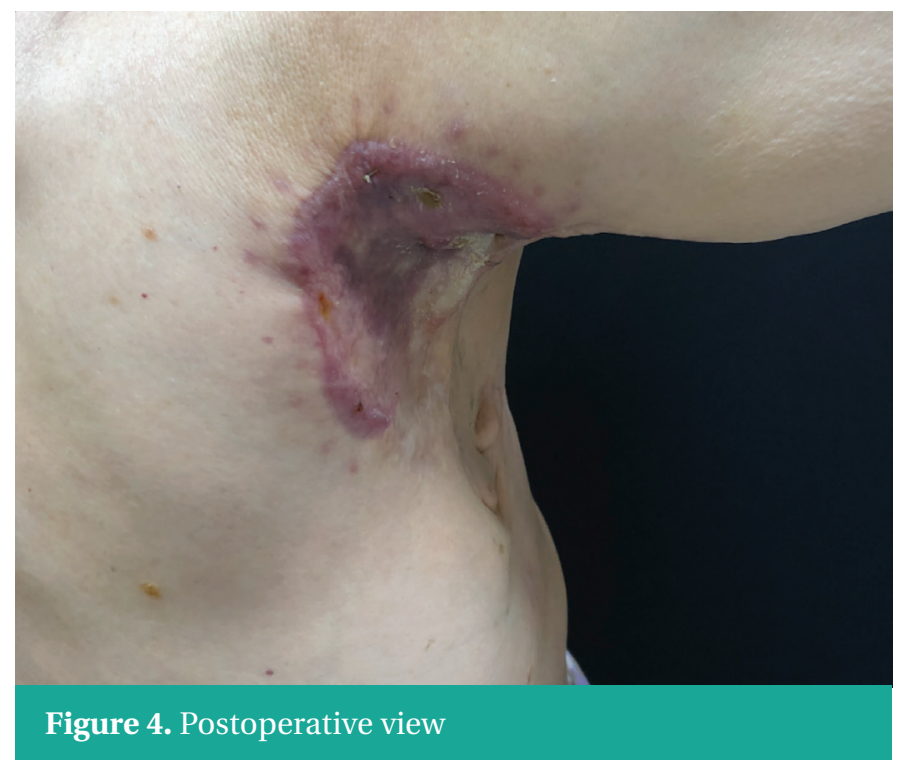

Wang et al. (19) presented six criteria to determine the malignancy of the tumor. Necrosis, spindle cell shape, vesicular nucleus having large nucleolus, high mitosis rate, height of cytoplasma/nucleus ratio and pleomorphism. With two of these criteria they define such a mass "atypical" and with three or more criteria as "malignant".

Histopathological confirmation is the gold standard in the diagnosis of GCT.

The tumor may cause a painless mass in the breast. The most common localization is upper middle and medial part (6). The tumor mimics breast cancer because it retracts nipple and skin. 5-8\% of GCTs are seen in the breast, most of these tumors are benign but $1-2 \%$ have malignant features (9). GCT mimics breast cancer because of showing irregulation, spiculation stellation, isodensity and heterogeneity on USG or mammography. Also, excisional biopsy is the gold standard for effective diagnosis and treatment. Recurrence rate with wide excision is $2-8 \%$ (20).

\section{Conclusion}

GCTs in the axilla are usually associated with the focus in the breast due to the similarity. In our case, the mass in the axilla was found to be malign GCT which is derived from skin, which malignancy is a rare condition for GCT.

\section{Ethics}

Informed Consent: Informed conset was signatured by patient.

Peer-review: Externally peer-reviewed.

\section{Authorship Contributions}

Surgical and Medical Practices: B.E.T., Concept: M.S., Design: P.K., Data Collection or Processing: C.G., Analysis or Interpretation: S.K., Literature Search: C.U., Writing: B.E.T.

Conflict of Interest: No conflict of interest was declared by the authors.

Financial Disclosure: Conflict of interest was declared by the authors.

\section{References}

1. Chen J, Wang L, Xu J, Pan T, Shen J, Hu W, et al. Malignant granular cell tumor with breast metastasis: a case report and review of the literature. Oncology letters 2012;4:63-66.

2. Weber CO and Virchow R. Anatomische Untersuchung einer hypertrophischen Zunge nebst Bemerkungen über die Neubildung quergestreifter Muskelfasern. Virchows Archiv 1854;7:115-125. 
3. Abrikossoff AI. Weitere untersuchungen über myoblastenmyome. Virchows Archiv 1931;280:723-740.

4. Gogas J, Markopoulos C, Kouskos E, Gogas H, Mantas D, Antonopoulou Z, et al. Granular cell tumor of the breast: a rare lesion resembling breast cancer. European journal of gynaecological oncology 2002;23:333-334.

5. Pergel A, Yucel AF, Karaca AS, Aydin I, Sahin DA, Demirbag N. A therapeutic and diagnostic dilemma: granular cell tumor of the breast. Case reports in medicine 2011. https://doi. org/10.1155/2011/972168.

6. Adeniran A, Al-Ahmadie H, Mahoney MC, Robinson-Smith TM. Granular cell tumor of the breast: a series of 17 cases and review of the literature. The breast journal 2004;10:528-531.

7. Rosso R, Scelsi M, Carnevali L. Granular cell traumatic neuroma: a lesion occurring in mastectomy scars. Archives of pathology \& laboratory medicine, 2000;124:709-711.

8. Aoyama K, Kamio T, Hirano A, Seshimo A, Kameoka S. Granular cell tumors: a report of six cases. World journal of surgical oncology 2012;10:204

9. Brown AC, Audisio RA, Regitnig P. Granular cell tumour of the breast. Surgical oncology 2011;20:97-105.

10. Tsuneyoshi M, Enjoji M. Granular cell tumor. A clinicopathologic study of 48 patients. Fukuoka Acta Med 1978;69:495-505.

11. Battistella M, Cribier B, Feugeas JP, Le Pelletier F, Pinguier F, et al. Vascular invasion and other invasive features in granular cell tumours of the skin: a multicentre study of 119 cases. Journal of clinical pathology 2014;67:19-25.

12. Gualis J, Carrascal Y, de la Fuente L, Echevarría JR. Heart transplantation treatment for a malignant cardiac granular cell tumor: 33 months of survival. Interactive cardiovascular and thoracic surgery 2007;6:679-681.
13. Jiang M, Anderson T, Nwogu C, Tan D. Pulmonary malignant granular cell tumor. World journal of surgical oncology 2003;1:22.

14. McGuire LS, Yakoub D, Möller MG, Rosenberg A, Livingstone A. Malignant granular cell tumor of the back: a case report and review of the literature. Case reports in medicine 2014. http://dx.doi. org/10.1155/2014/794648

15. Berg JC, Tewari KS, Rosario RD, Berman ML. Unusual presentation of a malignant granular cell tumor of the pelvis: case report and literature review. Gynecologic oncology 2003;90:224-230.

16. Ravich A, Stout AP, Ravich RA. Malignant granular cell myoblastoma involving the urinary bladder. Annals of Surgery 1945;121:361-372.

17. Schmidt O, Fleckenstein GH, Gunawan B, Füzesi L, Emons G. Recurrence and rapid metastasis formation of a granular cell tumor of the vulva. European Journal of Obstetrics \& Gynecology and Reproductive Biology 2003;106:219-221.

18. Yoshizawa A, Ota H, Sakaguchi N, Kanai S, Nakayama J, Matsuzawa $\mathrm{K}$, et al., Malignant granular cell tumor of the esophagus. Virchows Archiv 2004;444:304-306.

19. Wang J, Zhu X, Zhang RY. Malignant granular cell tumor: a clinicopathologic analysis of 10 cases with review of literature. Zhonghua bing li xue za zhi=Chinese journal of pathology 2004;33:497-502.

20. Quiroz-Rodriguez G, Robles-Vidal C, Guzmán-Navarro L, OrtizHidalgo C. Granular cell (Abrikossof) tumor of the breast. The breast journal 2006;12:494-494. 